\title{
Intensification of the provision of additional hotel services as a factor in the development of business tourism in the city of Rostov-on-Don
}

\author{
Antonina Petrenko ${ }^{1 *}$, Galina Ekinil ${ }^{1}$, and Valeria Provotorina ${ }^{1}$ \\ ${ }^{1}$ Don State Technical University, Gagarina Sq., 1, Rostov-on-Don, 344003, Russia
}

\begin{abstract}
This study is aimed at analyzing the peculiarities of the functioning of the hotel services market in the city of Rostov-on-Don and the Rostov region and identifying the specifics of providing additional hotel services by hospitality industry enterprises positioning themselves as congress hotels, hotels offering conference services. The article evaluates the total number of rooms for accommodation in the city of Rostov-onDon of a business nature and the range of additional hotel services provided by them.
\end{abstract}

\section{Introduction}

The hotel business is primarily associated with the provision of hotel services and is mainly focused on meeting the needs of tourists, including holidaymakers arriving for business purposes. A modern hotel enterprise should be not just a place to sleep, but an organization where the client can receive a full range of necessary services, including transfers, meals, conference rooms, and personal services.

Modern trends in the development of the hotel industry are aimed at expanding the range of services in hotels for various purposes. Currently, in the formation of the market attractiveness of a hotel company, additional services are becoming increasingly important. Additional hotel services allow you to receive additional benefits along with the benefits from the sale of the main product, as well as help to distinguish the main product from competing products. The system of additional services, unlike other parts of the hotel business, requires non-standard approaches to solving many issues. Correct organization of the process of implementation and provision of additional services makes it possible to expand the list of offers for hotel customers and attract additional categories of consumers.

The list and quality of the provision of paid additional services must meet the requirements of the category assigned to the hotel. The list of services is constantly being supplemented, modified and differentiated depending on the size of the hotel, its location, level of comfort and other reasons.

Since it is the additional services that can distinguish the hotel from other competitors, the study of the organization and technology of providing additional services is becoming increasingly important.

\footnotetext{
* Corresponding author: takyin_d@mail.ru
} 
The purpose of the work is to analyze the specifics of the organization and provision of additional hotel services in accommodation facilities of the city of Rostov-on-Don and to study their impact on the development of business tourism in the Rostov region. The increasing complexity and differentiation of human needs contributes to the expansion and improvement of the system of providing additional services in the hotel industry. The development of the system of additional services contributes to the establishment of the hotel business as a branch of economic activity, which over time brings more and more stable income. Variety and versatility in the list of additional hotel services provided allows the hotel to win the competition in the hotel services market. The hospitality industry, being an integral part of business tourism, performs one of the main functions in the service sector - providing tourists with accommodation, household and business services while traveling. Hospitality services are in demand with a highly segmented focus, where a wide variety of quality and level of service can be encountered. Despite everything, it remains attractive for both entrepreneurs and investors of the city. Currently, there is a need to intensify the provision of additional hotel services of a business nature to attract tourists to the Rostov region, primarily for business purposes.

Taking into account the prospects for the development of business tourism on the territory of the Rostov region, it is necessary to summarize the experience of foreign countries in which such tourist projects are most successfully implemented; to expand the number of rooms for business accommodation; increase the range of additional business services provided; to develop programs of business events in the Rostov region.

\section{Materials and methods}

In the modern world, it is impossible to be on the sidelines and not take into account the global trends of the industry, since sooner or later they will have to be taken into account in strategies and practical steps. That is why it is extremely important to study the experience of European countries and closely follow global trends both in practice and in research and analytical work.

The issues of providing additional services in hotel enterprises are disclosed in the works of the following authors: Özgür Davras, Meltem Caber 2019 [1], Asunción BeerliPalacio, Josefa D. Martín-Santana, Crisanto Román-Montoya 2020 [2], Shan Liu, Baojun Gao, Ye Gallivong 2020 [3], Seongsoo Jang, Luiz Moutinho 2019 [4].

The research of trends and peculiarities of the hotel business development in the world and in Russia is the subject of works of such authors as: A. O. Nabil, Channouf Asma AlZaidi, 2016 [5], Mehmet Ali Köseoglu, Mehmet Altin Eric Chan, Omer Faruk Aladag, 2020 [6], M.S. Oborin, 2018 [7], S.N. Moreva, E.V. Zobova, L.A. Yakovleva, 2017 [8], N.Y. Goryushkina, D.V. Shkurkin, A.S. Petrenko, S.Y. Demin, N.S. Yarovaya, 2016 [9], L.N. Kazmina, V.S. Makarenko, V.V. Provotorina, T.N. Grigorenko, G.E. Ekinil, E. MShevchenko [10-15], Ivanov V., Popov S., Dontsov N., Ekinil G., Oleynikova Ju., Denisenko Ju. [16].

The research methodology of tourism in the context of regional specifics is devoted to the works of such authors as: S. Karampela, D. Kavroudakis, T. Kizos, 2019 (experience of Greece) [17], T.Y. Dewanti, D. Susiloningtyas, Supriatna, 2019, (Indonesian experience) [18], S. Li, C. Li, J. Li, 2019, (China experience) [19], J. Cheng, Jing Xu, Zhenfang Huang, 2019 [20], Sami Chaabouni, 2019 [21], Virgil Nicula, Simona Spânu, Roxana Elena Neagu, 2013, (the experience of Romania) [22], Daniela Doina Fundeanu, 2015 [23], HAM Shaffril, A. Hamzah, S. Md. Yassin, B.A. Samah, J.L. D'Silva, N. Tiraieyari, M. Muhammad [24], A.Yu. Aleksandrova [25] Ekinil, G., Gorgadze, L., Provotorina, V., Petrenko, A. [26], Ekinil, G., Gorgadze, L., Yuryeva, O. [27] and others. 
Additional services are an indispensable component of any hotel's activities. Regardless of the type, size, specialization and location, most accommodation facilities seek to provide the client with an extensive list of additional services. Since, on the one hand, it is a way to attract customers in a competitive hotel market, and on the other hand, it is a real way to increase the profitability of a hotel. According to research, the share of additional services in the hotel's turnover can reach $43 \%$.

A number of functions and types of additional services should be highlighted:

1 Function, to facilitate the stay of people in the hotel:

- informational (Internet access, postal, telegraph services, information materials); order);

- utilities (laundry, dry cleaning); intermediary; car transport services (transfer, taxi

- provision of printed materials (magazines, newspapers); sale of goods (souvenirs).

2 Function for increasing comfort level:

- installation of additional equipment (projectors, mobile, microphones);

- pool organization;

- carrying out medical, cosmetic procedures.

3 Function, meeting special, specific requirements of guests:

- organization of personal excursions;

- providing a range of business services;

- baby service.

4 Function, enrichment of people's knowledge of the territory:

- excursions;

- visiting national holidays.

The determining factor for increasing the number and improving the quality of additional services is the orientation of the hotel company to a particular category of guests. In other words, their quantity and quality are directly related to the degree of demand and can be completely different. Thus, the key concepts in the mainstream of which any additional services exist can be considered justification and expediency.

Favorable development of this area of hotel activity is impossible without a successful combination of external and internal conditions, available resources that have a direct impact on the daily operation of the hotel, and competent management of this area of work. It is noteworthy that financial issues when organizing and developing additional services are not always in the foreground. In the system of additional services, as in any other part of the hotel business, non-standard approaches to solving many issues are in demand. This gives the hotel a small but real opportunity to stand out from the competition.

The research methodology is based on the use of a comparative analysis method, which made it possible to compare the accommodation facilities of the city of Rostov-on-Don in order to objectively assess their infrastructure and the specifics of providing basic and additional services. The use of the typification method made it possible to consider the existing accommodation facilities from the point of view of the peculiarities of the organization of services for business tourists. The long-term planning method was used to develop recommendations for intensifying the provision of additional hotel services in the hospitality industry enterprises of the city of Rostov-on-Don in order to attract business tourists and, as a result, develop business tourism in the Don region. The scientific provisions, conclusions and recommendations contained in the article are based on the use of the method of logical analysis and the economic-statistical method.

\section{Results}

The city of Rostov-on-Don is the capital of the Southern Federal District, a large city with a population of over one million on the right bank of the Don, with unique opportunities: a 
favorable geographical position, developed transport infrastructure, economic, intellectual and cultural potential. The climate, ready-made infrastructure, air and rail links with all million-plus cities, the largest agglomerations of the country are the unique advantages that the Don region has, attracting investors with favorable conditions for business development. The city is visited both for business and sightseeing and educational purposes. Today, many investment projects are being implemented here, offices of the largest companies and organizations are opening, numerous business and scientific meetings are held.

Currently, in Rostov-on-Don, there are more than 200 collective accommodation facilities of different levels, differing in location, service, comfort, capacity and prices (Fig. 1). All this makes it possible for the consumer of hotel services to make a competent choice of accommodation facilities. The structure of the hotel business in the region is quite diverse. Depending on the destination, the characteristics of the customer service categories and some other factors in the Rostov region, there are such types of accommodation facilities as: hotels, hotels, park hotels, boutique hotels, guest houses, motels, mini-hotels, hostels, furnished rooms, boarding houses, and other similar facilities, specially adapted for receiving and organizing the overnight stay of temporary visitors with different levels of service.

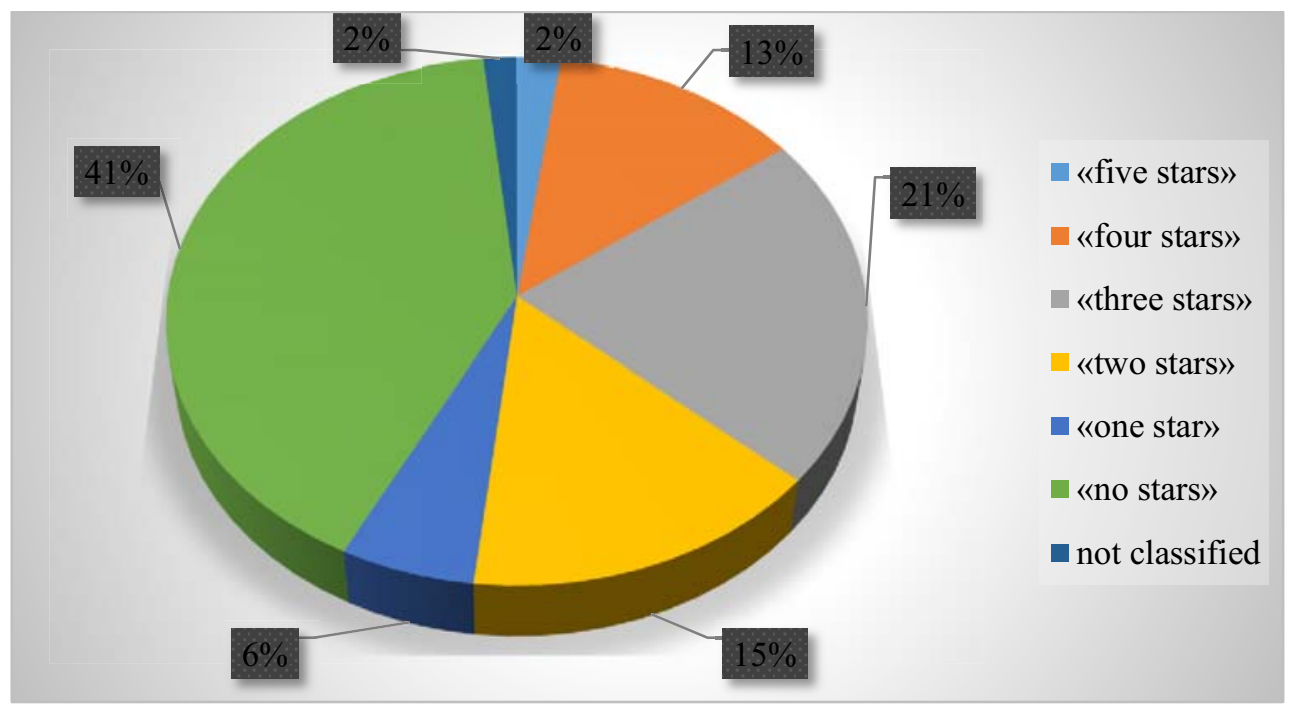

Fig. 1. Accommodation facilities in Rostov-on-Don.

According to the data of the register of tourist resources and subjects of the city's tourism industry, presented on the official tourist portal of the city of Rostov-on-Don, the total room stock of Rostov accommodation facilities is about 5300 rooms (Table 1). In addition, there is also the number of rooms adjacent to the city of Rostov agglomeration.

The leaders of the region note that the tourist flow to the region is growing annually, therefore, much attention is paid to infrastructure by increasing the number of hotels of different types and classes, renovating existing ones. However, there is a shortage of international-class hotels of "four" and "five" stars, because in spring and autumn - during the busiest times of business - the city has a shortage of rooms designed for wealthy guests.

The coefficient of provision with hotel rooms is one of the main criteria for the development of the hotel services market. In the city of Rostov-on-Don, the highest indicator of the provision of hotel rooms is in the "three stars" category. This category is considered the most common in Rostov hotels; almost all mini-hotels built over the past ten 
years operate in this format. The average cost of a room, including breakfast, excluding VAT, for a three-star hotel may exceed 2500 rubles / room / day, for a four-star hotel 4000 rubles / room / day, for a five-star hotel - 7100 rubles / room / day.

Table 1. Collective accommodation facilities of the city of Rostov-on-Don.

\begin{tabular}{|c|c|c|c|c|}
\hline No. & $\begin{array}{c}\text { Category of placement } \\
\text { facilities }\end{array}$ & $\begin{array}{c}\text { Number of placement } \\
\text { facilities, units }\end{array}$ & $\begin{array}{c}\text { Number of } \\
\text { rooms, units }\end{array}$ & $\begin{array}{c}\text { Number of } \\
\text { seats, units }\end{array}$ \\
\hline 1 & «five stars» & 5 & 222 & 421 \\
\hline 2 & «four stars» & 29 & 1004 & 1881 \\
\hline 3 & «three stars» & 49 & 1886 & 3143 \\
\hline 4 & «two stars» & 35 & 611 & 1180 \\
\hline 5 & «one star» & 13 & 290 & 595 \\
\hline 6 & «no stars» & 93 & 1178 & 2484 \\
\hline 7 & not classified & 4 & 90 & 170 \\
\hline & Total & 228 & 5281 & 9874 \\
\hline
\end{tabular}

Today, one of the main resources for the development of the hotel business in the city is business tourism. According to the regional administration, a guest spends on average one to three days in hotels in Rostov-on-Don. At the moment, the business segment, according to various estimates, provides about $70 \%$ of hotel occupancy. In the Rostov region, up to 500 congresses and conferences are held annually, as well as over 100 specialized exhibitions, mainly at the current moment events are held at the sites of hotel enterprises positioning themselves as congress hotels (Table 2).

Table 2. Congress-hotels of the city of Rostov-on-Don.

\begin{tabular}{|c|c|c|c|c|c|}
\hline No. & Type & Name & $\begin{array}{c}\text { Star } \\
\text { rating }\end{array}$ & $\begin{array}{c}\text { Number of } \\
\text { rooms }\end{array}$ & $\begin{array}{c}\text { Number of } \\
\text { conference } \\
\text { rooms }\end{array}$ \\
\hline 1 & $\begin{array}{c}\text { Congress } \\
\text { hotel }\end{array}$ & MarinsParkHotelRostov & 3 & 391 & 5 \\
\hline 2 & Hotel & Topos Congress Hotel & 3 & 150 & 12 \\
\hline 3 & Hotel & $\begin{array}{c}\text { Congress Hotel Don- } \\
\text { Plaza }\end{array}$ & 4 & 233 & 11 \\
\hline 4 & Hotel & $\begin{array}{c}\text { AMAKS Congress- } \\
\text { hotel }\end{array}$ & 3 & 287 & 4 \\
\hline
\end{tabular}

Congress hotel «Marins Park Hotel Rostov» is the largest hotel located in the central part of the city of Rostov-on-Don, with a tour desk and a business center. The hotel is 600 meters from Rostov-Glavny Train Station. There are several equipped conference rooms on the territory of the hotel, where there is a full range of multimedia equipment, mobile rearrangement of furniture for any type of event is possible, wireless Internet is available. The capacity of the conference rooms varies from 15 to 100 people.

The Topos Congress Hotel offers guests a multifunctional convention and exhibition center Don Expocentre. Business travelers can use one of 12 conference rooms with a capacity of 10 to 900 people for congresses and seminars, corporate negotiations and VIP services, press conferences, briefings and presentations. Also modern multimedia equipment (projectors, flip charts, laptops, microphones, etc.) can be rented. The Banquet Hall organizes banquets, coffee breaks, business lunches, buffets in the hotel. In the business center of the hotel, you can use office equipment, the Internet, courier and secretary-assistant services, book railway and air tickets, order express delivery of correspondence and cargo, transfer. 
The central business and information platform of the South of Russia is the Don-Plaza Congress Hotel. The hotel has already hosted over 1000 events of international, federal and regional significance. The ideal location and impeccable service attract government officials, heads of international companies, famous representatives of culture, science and other guests of Rostov to the hotel. The hotel offers 233 rooms for every taste: from the "standard" category to the presidential suites, services for organizing events, rent of conference rooms, business service.

«AMAKS Congress Hotel» offers its guests comprehensive services for both group and individual tourists, taking into account their individual preferences. In addition, the hotel offers services for the organization and conduct of business events of any complexity. The congress hotel has four conference rooms of different capacities, which are equipped with all the necessary modern presentation technology and equipment. The hotel's banquet hall staff organizes coffee breaks, lunches, dinners, banquet and buffet service. The hotel also offers the services of the entertainment center «Out Hall», where you can spend a pleasant evening in a relaxed atmosphere.

Congress hotels are a suitable option for both short business trips and longer stays in the city. The convenient location opens up opportunities not only for organizing cultural events, but also for fruitful business negotiations and presentations.

In addition to the above, conference services are also offered by 15 hotel enterprises in the city, presented in Table 3.

Table 3. Hospitality offering conference services.

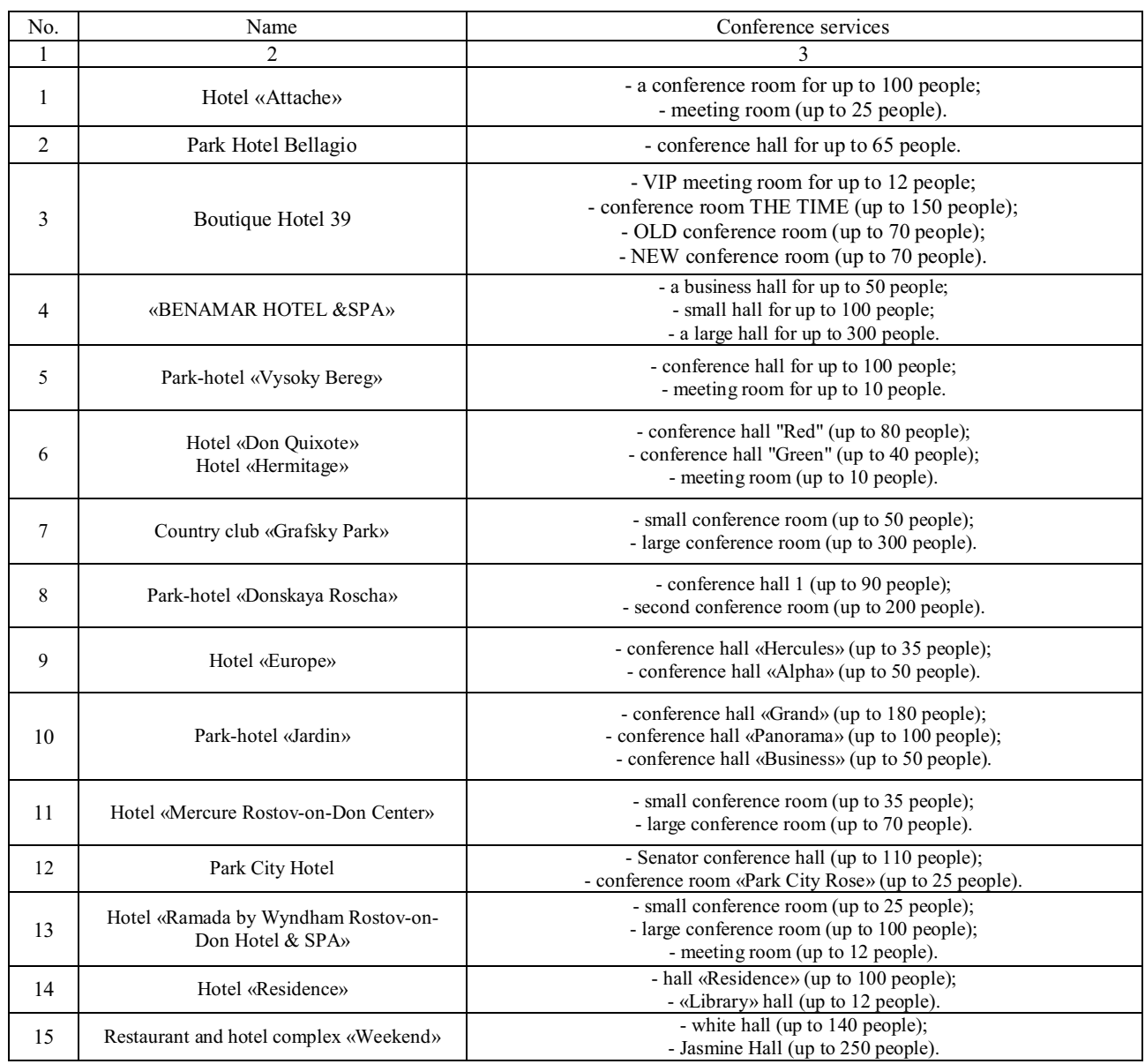


Hotels value the business travel industry as a source of high income, considering it a prerequisite for actively and successfully expanding the boundaries of hotel business. Currently, the market for conference services is led by hotel companies with a wide range of business services, positioning themselves as congress hotels. This specialization presupposes close attention to the needs of corporate clients, the hotel's orientation towards the business tourism segment as its main component, which raises the quality of all hotel services to a higher level.

One of the main requirements for congress hotels from the business clientele is to be located in the city center or near transport hubs. Also required: access to the Internet, longdistance telephone communications, cable and satellite television, spacious mobile and technically equipped conference rooms, business centers with a wide range of necessary services, restaurant catering, parking and the like.

The main service that a congress hotel should provide is the organization of business events, therefore, the infrastructure of such facilities should include conference rooms. The service becomes more popular if the provided sites are functional, well equipped for a wide range of official events (symposia, forums, seminars, creative meetings, master classes, round tables, exhibitions, business trainings, presentations, negotiations, meetings).

Modern hospitality establishments positioning themselves as congress hotels, in addition to conference rooms, offer a wide range of business services: a business center; photocopying, scanning and printing of documents; meeting room; banquet halls; the possibility of organizing meetings and various banquets, as well as special service from coffee breaks to official banquets; provision of translation services; WI-FI - Internet; telephone communication, organizing meetings, registration; professional branding of the hall; catering (breakfasts, lunches, coffee breaks, buffets, business dinners); information support (production and placement of banners, invitations, brochures, leaflets). For foreigners, guests from other cities, many congress hotels organize excursions, inspection sights.

The rooms in the congress hotels are equipped with the latest communication means and are maximally adapted not only for guests' recreation, but also for their full-fledged work. It offers guests in each room: several telephones with direct dialing and voice mail, a comfortable desk, the ability to connect to the Internet directly from the room. Each room has a personal electronic safe in which it will be convenient to store securities.

The accelerated development of the hospitality industry, the desire of hospitality companies to obtain the highest profits, and the growing solvency of consumers of business services contribute to the expansion and diversification of hotel activities. The range of services provided by hotel companies today is significant. Additional services are an indispensable component of any hotel business. The market for the hospitality industry in Rostov-on-Don is open and competitive, putting significant pressure on the industry, forcing it to constantly improve the quality of its services. The development of congress hotels and the intensification of the offer of business value-added services is the main prerequisite for the active and successful promotion of business tourism and the expansion of the boundaries of hotel activities.

\section{Discussion}

After analyzing the business tourism market of the city of Rostov-on-Don, one should highlight the key trends in its development: the predominance of individual business trips; a systematic increase in demand for attending industry exhibitions, event events; development of congress and exhibition tourism; development of the incentive tourism sector. Taking into account the need to position the Rostov region as an attractive tourist and recreational center of the Russian Federation, it becomes necessary to develop business 
tourism based on the latest information technologies in this industry as one of the directions for intensifying the provision of additional hotel services.

Effective provision of information, tourist and other services to business tourists coming to the Rostov region, as well as advertising, statistical and marketing activities, provides for the creation of a unified information support system - tourist information terminals with interactive systems «TouchInform» based on hospitality enterprises. One of the main tasks of the terminals will be to promptly provide all interested persons and organizations with information about the subjects of the tourism industry and the tourism resources of the Rostov Region, event events held in the region, the operating hours of tourist display facilities and transport, and other necessary information. Multilingualism of tourist information terminals will create a comfortable environment for foreign citizens. All interactive terminals are adapted to create a barrier-free environment for people with disabilities.

The main services of tourist information terminals include:

- providing guests with background information about the city of Rostov-on-Don and the Rostov region (historical data, cultural traditions, etc.);

- providing information about catering establishments (ordering, booking tables), transport services (car rental, transfer services), etc.;

- rendering assistance through communication services (telephony, video telephony, Internet, e-mail, etc.);

- assistance in purchasing transport tickets, booking them.

- assistance in purchasing tickets for entertainment and cultural events;

- organization of excursions, including those accompanied by a guide and an interpreter.

The introduction of tourist information terminals will allow receiving feedback from visitors and replenishing the customer database by conducting surveys and questionnaires; identify underperforming employees based on customer feedback and respond quickly to problems.

The advantages of installing a tourist information terminal in the hotel:

- savings (the terminal can replace the services of personnel, which will save on the maintenance of the workplace);

- availability;

- efficiency (possibility of round-the-clock work);

- informativeness. Modern technologies allow constantly updating the terminal information, which makes it possible to provide customers with the latest information and news;

- ease of use (simple interface);

- multifunctionality (unlimited possibilities, use for various purposes).

The provision of information to business tourists through tourist information terminals will be carried out with the help of audio and video materials, maps and diagrams, guidebooks, information and advertising guides free of charge.

Based on the results of the implementation of the introduction of tourist information terminals, it is predicted: an increase in the number of business tourists arriving in the Rostov region; increasing the number of accommodation facilities; an increase in the volume of paid tourist services; creation of additional jobs. Implementation of the introduction of tourist information terminals will allow: to overcome the factors hindering the development of business tourism in the Rostov region; create a competitive regional tourism product; more efficiently use human, informational, material and other resources; to ensure the attractiveness and increase the competitiveness of the Rostov region as a tourist and business destination. 
The effective development of tourism will significantly increase the flow of tourists and the flow of financial revenues to the economy of the Rostov region, as well as, taking into account the multiplier effect of tourism, the development of related sectors of the economy and an increase in employment.

\section{Conclusions}

Summing up, it should be noted that such concepts of the hotel industry and tourism are closely interrelated, and the development of each of them is not possible without each other. Thus, expanding the number of rooms in the hotel industry and improving the quality of service creates the necessary infrastructure for accommodating business tourists. On the other hand, the organization and holding of various types of business events, both national and international, will ensure the loading of the congress hotels. The growth of the business tourism market has already become the reason for the emergence of a symbiosis between a business center and a hotel as a multifunctional complex that combines office, hotel and retail space. A modern congress hotel should combine the capabilities of the infrastructure of a business center, a leisure center, as well as trade and service enterprises. When choosing a hotel for business, potential consumers pay attention to a number of factors. Namely - the competence and professionalism of the staff, the image of the institution, technical equipment, communication services, comfort and the like. Business tourists form the main share in the structure of tourist flows and demand for rooms in 4-5 stars hotels. Therefore, the expansion of the range of business services in the accommodation facilities of the city of Rostov-on-Don will attract a greater number of business tourists, thereby providing a contribution to the infrastructure of business tourism in the region and will contribute to its further development. Business tourism will act as a modern and effective tool for the development of territories, increase the well-being of the population, provide an inflow of investments, implement innovative projects and can contribute to the development of social infrastructure.

An increase in the number of accommodation facilities of a business nature and an expansion of the range of additional services will provide jobs, raise the standard of living due to an increase in income of the population and an increase in income of local budgets, will contribute to the development of small business, which will affect the solution of important socio-economic problems of the Don region.

\section{References}

1. Ö. Davras, Journal of Hospitality Management, 81, 83-93 (2019), https://doi.org/10.1016/j.ijhm.2019.03.003

2. A. Beerli-Palacio, J. D. Martín-Santana, C. Román-Montoya, International Journal of $\begin{array}{llll}\text { Hospitality } & \text { Management, } & \text { 87, } & 102458\end{array}$ https://doi.org/10.1016/j.ijhm.2020.102458

3. S. Liu, B. Gao, M. Gallivan, Ye. Gong, International Journal of Hospitality Management, 90, 102611 (2020), https://doi.org/10.1016/j.ijhm.2020.102611

4. S. Jang, L. Moutinho, International Journal of Hospitality Management, 78, 27-35 (2019), https://doi.org/10.1016/j.ijhm.2018.11.010

5. A. Oukil, N. Channouf, A. Al-Zaidi, Journal of Hospitality and Tourism Management, 29, 60-68 (2016)

6. M. A. Köseoglu, M. Altin, E. Chan, O. F, Aladag, International Journal of Hospitality Management, 89, 102574 (2020) 
7. M.S. Oborin, Tourism and Hospitality, 1, 2-17 (2018)

8. S.N. Moreva, E.V. Zobova, L.A. Yakovleva, Socio-Economic Phenomena and Processes, 12 (5), 100-105 (2017)

9. N.Y. Goryushkina, D.V. Shkurkin, A.S. Petrenko, S.Y. Demin, N.S. Yarovaya, International Review of Management and Marketing, 6(S6), 207-213 (2016)

10. L.N. Kazmina, V.S. Makarenko, V.V. Provotorina, T.N. Grigorenko, International Journal of Economics and Business Administration, 7, 510-520 (2019), doi: $10.35808 / \mathrm{ijeba} / 297$

11. L.N. Kazmina, V.V. Provotorina, Humanities and Socio-Economic Sciences, 5(96), 109114 (2017)

12. V.V. Provotorina, L.N. Kazmina, A.S. Petrenko, G.E. Ekinil, E3S Web of Conferences, 175, 10002 (2020), doi: 10.1051/e3sconf/202017510002

13. L.N. Kazmina, V.S. Makarenko, V.V. Provotorina, E3S Web of Conferences, 175, 10001 (2020), doi:10.1051/e3sconf/202017510001

14. V.V. Provotorina, L.N. Kazmina, A.S. Petrenko, V.S. Makarenko, Lecture Notes in Civil Engineering, 130, 20-32 (2020), doi.org/10.1007/978-981-33-6208-6_3.

15. G. Ekinil, V. Provotorina, A. Petrenko, L. Gorgadze, E3S Web of Conferences, 217, 05006 (2020), doi.org/10.1051/e3sconf/202021705006

16. V. Ivanov, S. Popov, N. Dontsov, et al., E3S Web of Conferences, 175, 05023 (2020)

17. S. Karampela, D. Kavroudakis, T. Kizos, Current Issues in Tourism, 22(12), 14601479 (2019), doi:10.1080/13683500.2017.1379475

18. T.Y. Dewanti, D. Susiloningtyas, IOP Conference Series: Earth and Environmental Science, 355(1), 0120553 (2019), doi:10.1088/1755-1315/355/1/012055

19. S. Li, C. Li, J. Li, Asia Pacific Journal of Tourism Research, 24(11), 1079-1091 (2019), doi:10.1080/10941665.2019.1665556

20. J. Cheng, X. Jing, H. Zhenfang, Habitat International, 87, 1-10 (2019), doi:10.1016/j.habitatint.2019.03.011

21. S. Chaabouni, Journal of Destination Marketing \& Management, 11, 183-191 (2019), doi:10.1016/j.jdmm.2017.09.002

22. V. Nicula, S. Spânu, R.E. Neagu, Procedia Economics and Finance, 6, 530-541 (2013), doi:10.1016/S2212-5671(13)00171-8

23. D.D. Fundeanu, Procedia Economics and Finance, 23, 744-749 (2015), doi:10.1016/S2212-5671(15)00501-8

24. H.A.M. Shaffril, A. Hamzah, S.M. Yassin, et al., Asia Pacific Journal of Tourism Research, 3(20), 295-313 (2015), doi:10.1080/10941665.2013.877048

25. A.Y. Alexandrova, Modern Problems of Service and Tourism, 14(1), 7-15 (2020), doi: 10.24411 / 19950411-2020-10101

26. G. Ekinil, L. Gorgadze, V. Provotorina, A. Petrenko, IOP Conference Series: Materials Science and Engineering, 1001(1), $012118 \quad$ (2020), doi:10.1088/1757899X/1001/1/012118

27. G. Ekinil, L. Gorgadze, O. Yuryeva, E3S Web of Conferences, 210, 18050 (2020), doi.org/10.1051/e3sconf/202021018050 